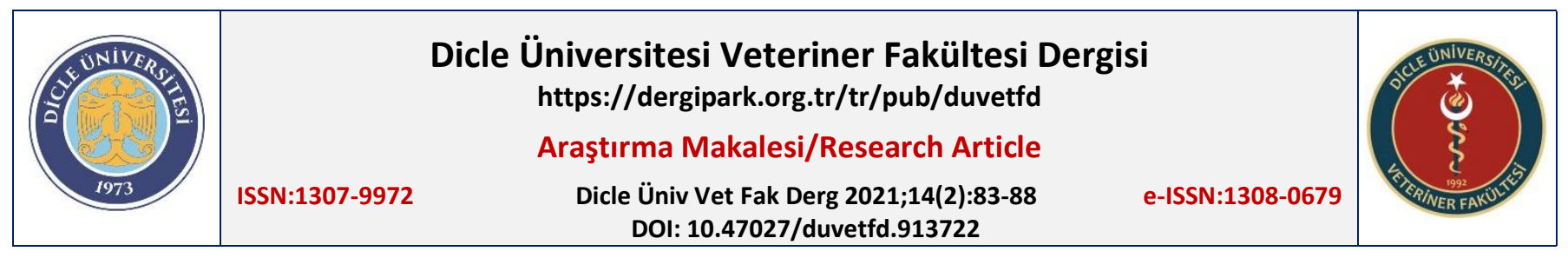

\title{
Yetişkin Boğa ve Koçların Testis ve Epididimal Kanal Ünitesindeki Vimentinin İmmünohistokimyasal Dağılımı
}

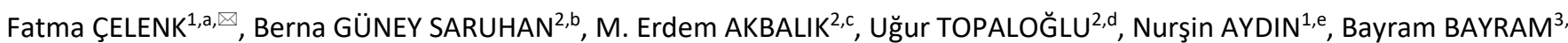

1Diyarbakır Tarım ve Orman İ Müdürlüğü, Gıda ve Yem Şube Müdürlüğü, Diyarbakır, TÜRKiYE

${ }^{2}$ Dicle Üniversitesi, Veteriner Fakültesi, Histoloji-Embriyoloji Anabilim Dalı, Diyarbakır, TÜRKiYE

3̧̧̧ırnak Üniversitesi, İdil Meslek Yüksek Okulu, Laborant ve Veteriner Sağlık Bölümü, İdil/Şırnak, TÜRKiYE

aORCID: 0000-0002-9677-8372; bORCID: 0000-0002-5111-5424; ' CORCID: 0000-0001-9898-0593; dORCID: 0000-0002-8306-491X

eORCID: 0000-0003-0265-3163; fORCID: 0000-0002-5738-918X

\begin{tabular}{ccc}
\hline Geliş Tarihi/Received & Kabul Tarihi/Accepted & Yayın Tarihi/Published \\
12.04 .2021 & 24.05 .2021 & 31.12 .2021 \\
\hline
\end{tabular}

Öz

Çalışma hücre iskeletinin yapısına giren vimentin proteininin boğa ve koç testis, epididimis, duktus deferens ve rete testis deki lokalizasyonlarını ortaya koymak amacıyla planlandı. Araştırmada, 8 adet sağlıklı, yetişkin boğa ve koçtan alınan doku örnekleri kullanıldı. İmmunohistokimyasal boyamalar için Strept-ABC boyama metodu uygulandı. Bu çalışmada, boğalarda ve koçlarda incelenen alanlarda vimentin immunoreaktivitelerinin dağılımının farklı olmadığı görüldü. Vimentin immunoreaktivitesi, seminifer tubüllerdeki Sertoli hücrelerinin perinüklear sitoplazmalarında, intertubüler alanlarda Leydig hücrelerinde ve rete testis epitelleri ile kan damarı endotellerinde belirlendi. Sonuç olarak, Sertoli ve Leydig hücreleri ile rete testis epitel hücrelerinin vimentin intermediyer filamanlarını içermesi, boğa ve koç testislerinde bu yapıların mezenşimal kökenli olduğunun belirtisidir. Ayrıca vimentin filamentlerinin Leydig hücrelerinde pozitif boyanması mikrotubüllerin hücresel salgı ürünlerinin taşınmasında aktif bir rol oynadığının göstergesidir. Böylelikle vimentin filamentlerinin erkek genital sistemde hücre iskeletine desteklik sağlama, spermatogenezisin olgunlaşması ve korunması gibi önemli rolleri üstlendiği gösterilmiştir.

Anahtar Kelimeler: Vimentin, testis, epididimis, duktus deferens, rete testis

\section{Immunohistochemical Distribution of Vimentin in the Testis and Epididymal Duct Unit of Adult Bulls and Rams}

\section{Abstract}

This study was planned to determine the immunohistological localization of vimentin proteins that which enters the structure of the cytoskeleton, in bull and ram testes, epididymis, ductus deferens and rete testis. The testis, epididymis, deferens and rete testis patterns taken from eight healthy, adult, male bull and ram formed the material of our study. For the determination of the localization of vimentin, a strept-ABC immunohistochemical staining procedure was applied. In this study it was observed that, the distribution of vimentin immunoreactivities was not different in the areas examined in bulls and rams. The vimentin immunoreactivity was determined in perinuclear cytoplasm of Sertoli cells, epithelium of tubuli recti and rete testis, and endothelium of blood vessels. In conclusion, the vimentin is found in the Sertoli and Leydig cells and epithelium of rete testis suggest that those structures are derived from mesoderm. In addition, the positive staining of the vimentin filaments in Leydig cells indicates that the microtubules play an active role in the transport of cellular secretory products. Thus, it has been shown that vimentin filaments play important roles such as providing support to the cytoskeleton in the male genital system, maturation and protection of spermatogenesis.

Key Words: Vimentin, testis, epididymis, ductus deferens, rete testis

\section{GiRiş}

Hücre iskeleti (sitoskeleton), mikrofilamanlar (aktinler, 6-7 $\mathrm{nm}$ ), intermediyer filamanlar (sitokeratinler, vimentin, desmin, 8-10 nm) ve mikrotubüluslardan (tubülinler, $25 \mathrm{~nm}$ ) meydana gelen protein tabiatındaki sitosolik bir oluşumdur. Bu bileşenler birbirleriyle yakın ilişkidedir ve hücre iskeletini meydana getirir. Bu proteinlerin hücre yapısı ve fonksiyonları üzerindeki başlıca görevleri; hücreye şekil verme, kutuplaşma, organellerin konumlandırılması, sitoplazmik uzantıların desteklenmesi ve organellerin hücre membranına bağlanması olarak açıklanmaktadır. Intermediyer filamanlar, yapısal olarak birbirlerine benzeyen ancak kimyasal olarak birbirinden farklı birçok ara filamentten oluşan ve farklı hücrelerde yerleşim gösteren yapılardır. Başlıca; sitokeratinler (epitel hücreleri), vimentin (mezenşimal hücreler), desmin (kas hücreleri), nörofilamentler (sinir hücreleri) ve gliyal fibriler protein (gliya hücreleri) olmak üzere beş alt gruba ayrılmaktadır $(1,2)$.

Memelilerin üreme organlarında ve eşey hücrelerini ileten yollarında mikrofilamentlerin ve ara filamentlerin immünohistokimyasal olarak gösterilmesi son zamanlarda ilgi görmesine rağmen buradaki rolleri halen çok net değildir. Ara 
filamentler kökeni ve hücre tipi farklı proteinler tarafından oluşturulan ve testiste Sertoli hücreleri, peritübüler-miyoid hücreler ve Leydig hücreleri dahil birçok hücre tipinde bulunan hücre iskeleti bileşenlerine ait proteinlerdir (1). Hipofiz bezinden salgılanan gonadotropinlerinin testisin genel işlevini kontrol etmesiyle birlikte, hücreler arasında gerçekleşen kontrol mekanizmaları da önem arz etmektedir. Mikrotübül, mikrofilaman ve ara filaman modelleri, tek tek hücrelerin işlevsel durumunu yansıtmaya yardımcı olur.

Testis hücrelerinde bulunan 57 kDa moleküler ağırlığına sahip olan vimentin, orjini çeşitli birçok hücre tipinde mevcut olan bir ara filamentdir (çap 7-11 nm) $(3,1)$. Bulunduğu hücrelerde başlıca organellerin yerini sabitleme, hücreye esneklik sağlamak ve hücre içinde kolesterol taşınması gibi önemli roller üstlenmiştir. Vimentin esas olarak çekirdek etrafında yoğunlaşır ve özel hücre içi yapılarla birlikte hücrenin apikal bölgesine doğru yayılır. Daha sonra Sertoli hücreleri ve komşu germ hücreleri arasında bulunarak, spermatogenezin korunmasında önemli bir rol oynar. Sertoli hücresi, seminifer epitelin temel yapısal unsuru olup, germ hücresi gelişimi ve olgunlaşmasına fiziksel destek ve elverişli bir ortam sağlar. Bu hücreler fonksiyonlarını gerçekleştirebilmek için aktin, vimentin ve tübülinden oluşan iyi gelişmiş bir hücre iskeletine sahiptirler. Puberte döneminde Sertoli hücreleri, hücre iskeletinde değişikliklere neden olan bir seri dönüşüm geçirir. Hücre iskeleti üzerindeki bu değişiklikler özellikle FSH hormonunun etkisi altında olmaktadır. Sertoli hücrelerinde dominant intermediyer filaman, özellikle çekirdek etrafında lokalize olan ve hücreye yapısal bir destek sağlayan vimentindir. Sertoli hücresi ve yakınındaki hücreler arasında bulunan vimentinin yapısal destek, plazma membran-çekirdek iletişimi ve nükleer konumlandırma gibi çeşitli işlevlere hizmet ettiği belirtilmiştir. Bununla beraber bugün halen vimentinin Sertoli hücrelerindeki işlevi iyi anlaşılamamıştır. Sertoli hücrelerinde vimentinin değişen dağılımı, bozulmuş spermatogenez ile bağlantılı olarak insan ve sıçan testislerinde bildirilmiştir $(1,2)$. Yine yapılan çalışmalarda, vimentin, Sertoli hücrelerinde, testis interstisyel hücrelerinde, rete testiste ve seminifer epitelden türetilmiş tümörlerde varlığı tespit edilmiştir (4). Yapılan çalışmalarda, memelilerin testis, rete testis, efferent kanalları ve epididimal kanal ünitesinde ve periduktal düz kas hücresi katmanında vimentin ara lifleri gösterilmiştir. $(5,6)$. Elektron mikroskobu ve immünositokimya çaIışmaları yoluyla Leydig hücre iskeletinin mikrotübüller, aktin filamentleri ve vimentin tipi ara filamentler içerdiği de tespit edilmiştir. Sıçan testis Leydig hücrelerinde, vimentinin steroid biyosentezinin düzenlenmesinde rol oynadığı kanıtlanmıştır (7).

Hücrelerin iskelet yapısını meydana getiren proteinlerin varlığı ve dağılımıyla ilgili insanlarda dahil olmak üzere sıçan, boğa, koç, köpek, maymun, domuz, ayı, lama ve kanatı gibi birçok türün testis ve epididimisinde çalışmalar mevcuttur (8). Yapılan bu çalışmalardan yola çıkarak, koç ve boğaların testis ve epididimisinde de ara filamentler arasında en yoğun olarak bulunan vimentinin immunohistokimyasal dağılımı ve bu dağılımlarında türler arasında farklılıklar olup olmadığını göstermek için bu çalışma planlanmıştır.

\section{MATERYAL VE METOD}

\section{Örneklerin Toplanması ve Tespit İşlemi}

Çalışmada, Diyarbakır ilinde yerel mezbahalarda kesilen sağlıklı ve erişkin 8 adet boğa ve koç testis dokusu kullanıldı. Numuneler alındıktan sonra 12 saat süre ile Bouin solüsyonunda tespit edildi. Daha sonra, dokular rutin histolojik prosedürleri (dehidrasyon, şeffaflaştırma, parlatma) takiben parafine bloklandı. Hazırlanan parafin bloklardan 5 mikrometre kalınlığında ve 100 mikron aralıklarla seri kesitler alındı. Daha sonra her bir parafin bloktan vimentin ekspresyon ve lokalizasyonlarını göstermek için iki adet (boğa, koç) preparat hazırlandı. Hazırlanan preparatlar her bir doku bölümü için en az üç kesit içermekteydi.

\section{İmmunohistokimyal Boyama}

İmmunohistokimyasal boyama yöntemi için Avidin-BiotinPeroxidase Kompleks $(A B C)$ prosedürü uygulandı. Kesitler, endojen peroksidazın inaktivasyonu amacıyla metanol ile hazırlanan \%3'luk hidrojen peroksitte 30 dakika süreyle tutulup $0.01 \mathrm{M}$ PBS ile $3 \times 5 \mathrm{dk}$ yıkandı. Antijen retrival işlemi için kesitler sitrat buffer (pH:6) solüsyonunda $20 \mathrm{dk}$ kaynatıldı. Daha sonrasında soğutuldu ve PBS'te $3 \times 5 \mathrm{dk}$ boyunca yıkandı. Kesitler, $10 \mathrm{dk}$ UV blokta inkübe edildi. Hazırlanan örnekler sonra 1/100 sulandırılmış vimentin fare monoklonal primer antikoru (catalog no: MS-129-R7 Thermo Scientific) ile $+4 \mathrm{C}$ de bir gece inkübe edildi. Bu sürenin sonunda kesitler $3 \times 5$ $0.01 \mathrm{M}$ PBS ile yıkandı. Sonrasında, oda sıcaklığında $20 \mathrm{dk}$ boyunca biotinlenmiş sekonder antikorda (Histostain Plus Bulk Kit, Zymed) tutuldu ve 0.01M PBS 3x5 dk yıkandı. Kesitler, 20 $\mathrm{dk}$ boyunca streptavidin-peroxidase (HRP) ile inkübe edildi ve sonrasında $3 \times 5 \mathrm{dk}$ PBS ile de yıkandı. Kesitlerde ortaya çıkacak antijen-antikor reaksiyonlarını göstermek için diaminobenzidine (DAP) kromojende 5-10 dk bekletildi. Zemin boyanması için 2 dk Gill'in Hematoksilende tutuldu. Alkol serilerinden geçirilip dehidrasyon işlemleri tamamlanan kesitler xylenle parlatılıp entellan ile kapatıldı. İmmünohistokimyasal işlemlerin özgüllüğü, negatif ve pozitif kontrol kullanılarak değerlendirildi. Pozitif kontrol olarak boğa ve koçların derileri kullanıldı. Negatif kontrol için primer antikorların yerine non-spesifik immun serum damlatılarak geriye kalan boyama işlemlerine normal boyamalarda olduğu gibi devam edildi. Boyanan preparatlar DS-RI1 video camera (DS-U3, Nikon, Tokyo, Japan) ile donatılmış araştırma mikroskop Nikon Eclipse E400 (Nikon, Tokyo, Japonya) kullanılarak fotoğraflandı.

\section{Yarı Kantitatif Değerlendirilme}

Kalitatif analiz, parafin giderilmiş ve yeniden hidratlanmış paraplast doku kesitlerinde gerçekleştirilmiştir. Dokular, daha önce tarif edildiği gibi immünohistokimyasal teknikler kullanılarak vimentinin görselleştirilmesi için işlendi. Vimentin boyanma yoğunluğu (IS) temel alınarak semikantitatif skorlama metodu kullanılarak yapıldı (9). IS hücrelerin membranlarındaki, sitoplazmalarındaki ve çekirdeklerindeki pozitif boyanma yoğunluğunu yansıtıyordu. Bu metotta immunohistokimyasal skorlama (-) negatif; (+) zayıf; (++) orta veya (+++) güçlü olarak değerlendirildi. Hücrelerdeki immunboyanma reaksiyonlarının IS'sı iki bağımsız araştırmacı tarafından 
değerlendirildi ve iki gözlemcinin ortalama puanı hesaplandı. Testis, epididimis, $d$. deferens ve rete testiste vimentin ekspresyonu X20, X40, X100 büyütmelerde mikroskop altında değerlendirildi. Bu dokuların herbir bölgesinde (epitel, bağdokusu, kas) herbir kesit için üç rastgele seçilmiş alan değerlendirildi. Sonuçlar epitel hücreleri, stromal hücreler, kas hücreleri, kan damarları ile sinir kesitleri için ayrı ayrı değerlendirildi ve sunuldu (Tablo 1 ).

Tablo 1. Boğa ve koç testis, rete testis, epididimis ve duktus deferensinde vimentin ekspresyon yoğunlukları

\begin{tabular}{llcc} 
Organ/ & Hücreler & \multicolumn{2}{c}{ Vimentin lokalizasyonu } \\
\cline { 3 - 4 } Bölümler & & Boğa & Koç \\
& Spermatogenik & - & - \\
& Spermatozoan & - & - \\
Testis & Sertoli & +++ & +++ \\
& Peritubüler myoid & - & - \\
& Leydig & +++ & +++ \\
Rete & Epitel & +++ & +++ \\
testis & Bağdoku & - & - \\
& Epitel & - & - \\
Duktus & Bağdoku & +++ & +++ \\
epididimis & Düz kas & +++ & +++ \\
& Epitel & - & - \\
Duktus & Bağdoku & +++ & +++ \\
deferens & Düz kas & +++ & +++ \\
\hline & & &
\end{tabular}

Şekil 1. A: Boğalarda testis seminifer tubüllerinde vimentin immunohistokimyasal lokalizasyonu. (ST) seminifer tubül, (]) spermatogenik hücreler, (siyah oklar) Sertoli hücreleri, (siyah ok başı) Leydig hücreleri, (KD) kan damarı, (yeşil ok) peritubüler myoid hücre, bar; $25 \mu \mathrm{m}$. B: Koçlarda testis seminifer tubüllerinde vimentin immunohistokimyasal lokalizasyonu. (ST) seminifer tubül, (]) spermatogenik hücreler, (siyah oklar) Sertoli hücreleri, (siyah ok başı) Leydig hücreleri, (yeşil ok) peritubüler myoid hücre, bar;25 $\mu \mathrm{m}$. C: Boğalarda testis seminifer tubüllerinde vimentin immunohistokimyasal lokalizasyonu. (ST) seminifer tubül, (]) spermatogenik hücreler, (siyah oklar) Sertoli hücreleri, (siyah ok başı) Leydig hücreleri, (yeşil ok) peritubüler myoid hücre, bar; $6.25 \mu \mathrm{m}$. D: Koçlarda testis seminifer tubüllerinde vimentin immunohistokimyasal lokalizasyonu. (ST) seminifer tubül, (]) spermatogenik hücreler, (siyah oklar) Sertoli hücreleri, (siyah ok başı) Leydig hücreleri, (yeşil ok) peritubüler myoid hücre, bar;6.25 $\mu \mathrm{m}$.

Genel olarak duktus epididimis ve duktus deferens kanal ünitesinin epitel segmentinde ve rete testis bağ doku hücrelerinde vimentin immunonegatifti (Şekil-2A,B,C, D, E, F). Bununla beraber yer yer epitel içerisinde pozitif boyanan intraepiteliyal lenfosit veya makrofaj olduğu düşünülen hücre görünümüne rastlanıldı (Şekil-2A, B). Rete testiste tüm epitel boyalıydı, ancak immünreaksiyon'nun epitelin bazal

\section{BULGULAR}

Bu çalışmada, boğalarda ve koçlarda incelenen alanlarda vimentin immunoreaktivitelerinin dağılımı́nın farklı olmadığı görüldü. Testis'in seminifer tubüllerindeki spermatogenetik seri hücrelerinde ve peritubüler myoid hücrelerinde vimentin boyanma izlenmedi (şekil 1A, 1B, 1C,1D). Bununla birlikte tubüller içerisindeki germ hücrelerinin farklı gelişim aşamalarında bulunma durumuna göre, vimentin filamanlarının Sertoli hücrelerinin perinüklear sitoplazmasıyla birlikte apikal veya bazal yerleşim gösterdiği ve bu görüntülerin özellikle bazal bölgeden tubül lümenine doğru uzanan mum alevi benzeri bir şekle sahip olduğu belirlendi (Şekil 1A, 1B, 1C,1D). Ayrıca intertubüler alanlardaki Leydig hücreleri ve damar endotellerindeki pozitif immunreaksiyon dikkati çekti (Şekil-1A, $\mathrm{B}, 1 \mathrm{C}, 1 \mathrm{D})$.
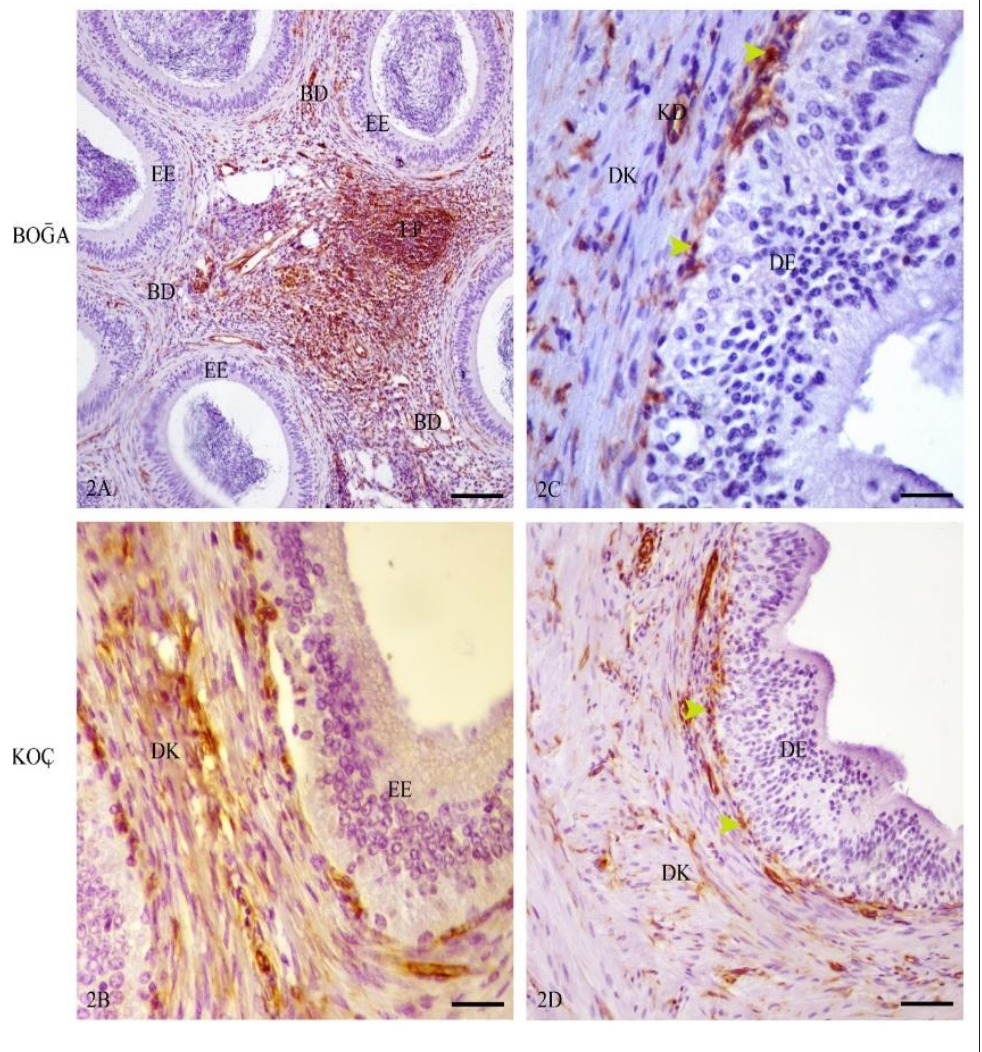

bölgesinde nispeten daha yoğun olduğu saptandı (Şekil $2 \mathrm{E}$, F). Kanallar içerisinde bağdoku alanlarına yerleşmiş lenf foliküllerinin, düz kas hücrelerinin ve sinir tellerinin pozitif boyanması da dikkat çekiciydi. İncelenen tüm testis ve kanalların lümenlerinde görülen spermatozoanlar vimentin immunonegatifti. 

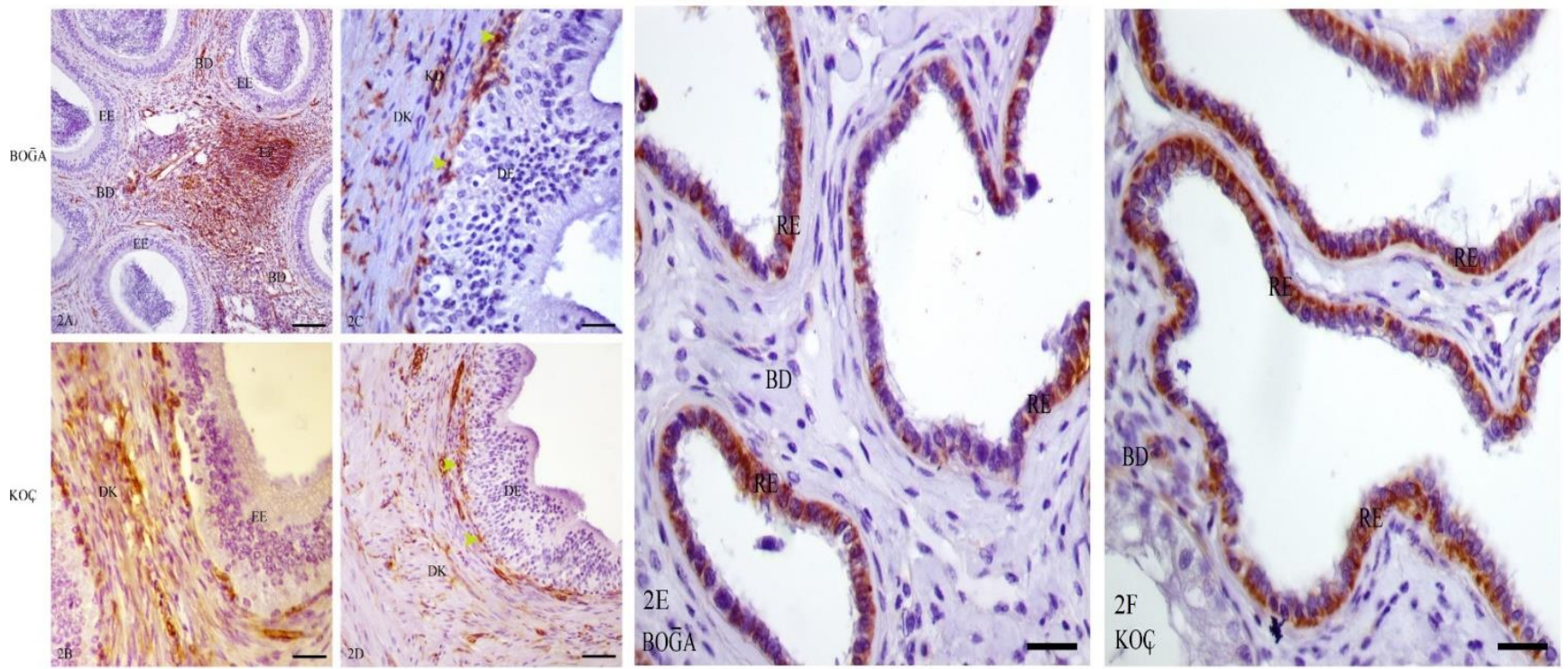

Şekil 2. A: Boğalarda duktus epididimiste bağdoku ve lenf foliküllerinde vimentin pozitif immun boyanma. (EE) epitel, (BD) bağ doku, (LF) lenf foliküli, bar;50 $\mu \mathrm{m}$. B: Koçlarda duktus epididimiste bağdoku ve düz kaslarda vimentin pozitif immun boyanma. (EE) epitel, (DK) düz kas, bar;25 $\mu \mathrm{m}$. C: Boğalarda duktus deferenste bağdoku ve düz kaslarda vimentin pozitif immun boyanma. (DE) duktus deferens epitel, (yeşil ok başı) bağdoku hücreleri, (DK) düz kas, (KD) kan damarı, bar;25 m. D: Koçlarda duktus deferenste bağdoku ve düz kaslarda vimentin pozitif immun boyanma. (DE) duktus deferens epitel, (yeşil ok başı) bağdoku hücreleri, (DK) düz kas, (KD) kan damarı, bar; $25 \mu \mathrm{m}$. E: Boğalarda rete testis epitelinde vimentin pozitif immun boyanma. $(\mathrm{RE})$ rete testis epiteli, $(\mathrm{BD})$ bağ doku, bar;25 $\mu \mathrm{m}$. F: Koçlarda rete testis epitelinde vimentin pozitif immun boyanma. (RE) rete testis epiteli, (BD) bağ doku, bar; $25 \mu \mathrm{m}$.

\section{TARTIŞMA VE SONUÇ}

Mevcut immünohistokimyasal çalışma, yetişkin boğa ve koç erkek üreme sisteminde hücre iskeleti proteinlerinden olan vimentin'in lokalizasyon modelini göstermeyi amaçlamıştır. Testis sahip olduğu özellikler sebebiyle fazla sayıda araştırmaya materyal olmuştur. Araştırmaların çoğunun insan, rat ve fare üzerinde yoğunlaştığı, diğer canlı türlerinde ise daha az sayıda olduğu görülmüştür (8). Çalışmamızda yetişkin koç ve boğa testisinde vimentin immün boyama'nın, her iki türde de aynı dağılımı gösterdiği ve genel anlamda da geviş getirenlerde ki dağılım modeli ile uyumlu olduğu gözlenmiştir. (10-14). Ayrıca seminifer tubüllerdeki spermatogenik hücrelerde vimentin immunoreaktivitesinin gözlenmemesi diğer çalışmalar tarafından da desteklenmiştir $(8-10,12,13)$. Öte yandan seminifer tubüller içerisindeki Sertoli hücrelerinin vimentin pozitif boyandığı ve birçok çalışma ile de benzer olduğu görülmüştür $(10,12,13,14)$. Vimentinin, Sertoli hücrelerinde oynadığı biyolojik rol tam olarak anlaşılamamakla beraber hücre iskeletinde var olan mikrofilaman ve mikrotübül ara filamanlarının hücrelere mekanik esneklik ve güç sağladığı uzun zamandır varsayılmıştır. Bununla birlikte, bu geleneksel kavramlara, vimentinin hücre sinyalleşmesinde bir rol oynayabileceği önerisi araştırıcılar tarafından güçlü bir şekilde ortaya konmuştur (15). Sertoli hücresinde görülen vimentin filamentleri, hem çekirdeği çevreleyen hem de germ hücrelerine bağlanma bölgesinde plazma zarı ile birleştikleri hücrenin etrafında uzanan apikal uzantılar şeklinde bulunurlar (16). Böylelikle bu filaman uzantılarının, Sertoli hücregerm hücre temaslarının bütünlüğünün korunmasında rol oynayabileceği düşüncesini öne çıkarabilir. Ayrıca, vimentin filamentlerinin Sertoli-germ hücre apoptotik sinyallemesini birleştirmede daha doğrudan bir role sahip olduğu fikrini de akla getirebilir. Vimentin ara lifleri, birçok ökaryotik hücrenin hücre iskeletinin önde gelen unsurları olmasına rağmen, bu liflere henüz herhangi bir hayati hücresel işlev atfedilmemiştir (16). Bununla birlikte, sitoplazmik ara ipliklerin plazma zarı ile etkileşime girdiğine dair güçlü yapısal, biyokimyasal ve doğrudan deneysel kanıtlar vardır (16). Bu nedenle, vimentinin apoptotik hücresel sinyal iletim yolu ile bağlantılı olabileceği düşünülebilinir $(16,17)$. Sertoli hücreleri, hem fiziksel destek hem de germ hücresinin hayatta kalması için gerekli olan faktörlerin salgılanmasını sağlar. Ayrıca Sertoli hücreleri, bu iki hücre türü arasında doğrudan-iletişim yoluyla germ hücre işlevini de etkileyebilir. Sertoli ve germ hücreleri yakın temas halindedir ve bağlantılarını gap junction veya taşıyıcı aracılıklı mekanizmalar yoluyla sağlayabilirler (16). Sıçan testislerinde seminifer tubüllerdeki germ hücrelerinin farklı gelişim aşamalarında olma durumlarına göre Sertoli hücrelerinde vimentin ekspresyonunun değişiklik gösterebileceği de bildirilmiştir (8). Bu durum vimentin'nin spermatogenez sırasında Sertoli hücrelerinin sitoplazmasında meydana gelen morfolojik değişikliklere uyum sağlamasına katkı sağlayabileceği şeklinde yorumlanmıştır. Yapılan çalışmalarda Sertoli hücrelerinde vimentin içeriğinin dağılımı fetal sıçanlarda ve erişkin koçlarda yaşa bağlı olarak artış göstermiştir $(13,14)$. Hayvanların yaşı ilerledikçe görünür vimentin miktarı artar, bu da bu bileşenlerin Sertoli hücrelerine olan desteğin ortaya çıkmasında önemli bir rol oynadığını düşündürür. Sunulan araştırmanın bu araştırmacıların bulgularıyla uyumlu olduğunu belirtebiliriz $(10,12,13,14)$. Sıçanlarda Sertoli hücrelerinde temelde bulunan vimentinin mikrofilamentlere bağlandığı gösterilmiştir $(18,19)$. Bir grup araştırmacı yaptıkları çalışmalarda insan, sıçan ve yer sincabının Sertoli hücrelerinde yapılan gözlemlerin aksine, seminifer epitel döngüsü sırasında yetişkin koç tübüler epitelinde vimentin immün boyamasında farklılık gözlemediklerini 
belirtmişlerdir $(7,20)$. Çalışmamızda intertubüler alanda bulunan Leydig hücrelerinde, damar endotel ve düz kas hücrelerinde vimentin pozitif boyanma izlenmiştir. Böylelikle diğer çalışmalarla uyumlu olacak şekilde çalışmamızda da mezenkim kökenli olan bu hücrelerin vimentin filamentlerini içerdiği gösterilmiştir $(8,14)$. Genel anlamda bu özelliğin mezenkimden türetilmiş hücrelerin genel bir özelliği olduğu söylenebilir. Leydig hücrelerinin kuvvetli vimentin immunreaksiyon göstermesi, mikrotubüllerin hücresel salgı ürünlerinin taşınmasında aktif bir rol oynadığını akla getirmiştir. Steger ve ark. (1994) pre-pubertal boğa ve koçlarda, Komatsu ve ark. (1998) ise, Japon kara ayılarının testislerinde gelişim aşamalarına göre peritübüler hücrelerde vimentin pozitif boyanma olduğunu bildirmiş̧lerdir $(10,13)$. Bunun aksine bazı araştırmalar $(8,10)$ gibi bizim çalışmamızda da yetişkin hayvanların peritubüler myoid hücrelerinde boyanmanın negatif olduğu görülmüştür.

Duktus epididimis, D. deferens ve rete testiste vimentin ara filamentlerinin ekspresyonuna bakıldığında, dağılım modelinin epididimis ve $\mathrm{D}$. deferense göre rete testiste farklılık gösterdiği gözlemlendi. İnsanlarda dağılım modelinde, yetişkin erkeklerin rete epitelinde vimentinin ipliksi yapısının iyi korunduğu ve boyanmanın özellikle de hücrelerin bazal bölgelerinde yoğunlaştığı ifade edilmiştir (6). Czernobilsky ve ark. (1985), rete ovarii ve rete testisin epitel hücrelerinde bizim çalışmamız ile tutarlı olan vimentin ekspresyonunu bildirmişlerdir (21). Bu durumda vimentin proteininin rete epitel hücrelerininin salgılama işlevinde aktif bir rol oynayabileceği düşünülmüştür. Epididimis ve $\mathrm{D}$. deferensin bağ dokuları içerisinde lokalize olan farklı hücrelerin ve düz kasların vimentin pozitif boyanması da "mezenkimden köken alan hücreler vimentin içerir" ifadesini desteklemektedir. Bununla birlikte, insanlarda $(6,22,23)$ ve köpeklerde $(24)$ bildirildiği gibi, bizim çalışmamızda da epididimis epitelinde vimentinin bulunduğu görülmüştür. Aire ve ark. (2008) ise, devekuşunda yaptıkları çalışmada epididimis epitel hücrelerinin vimentin negatif olduğunu bildirmişlerdir (5). Bu durumda, türler arasındaki bu farklılıkların hücresel işlevdeki farklılıklarla ilişkili olabileceğini düşündürmüştür.

Sonuç olarak, boğa ve koçlarda vimentin filamentlerinin testiste Sertoli ve Leydig hücrelerinden, rete testis epitelinden, bağdoku, endotel ve düz kas hücrelerinden eksprese olduğunu gösterdi. Böylelikle vimentin filamentlerinin söz konusu bu hücrelere mekanik esneklik ve mukavemet kazandırma yanında hücre iskeletine de desteklik sağladığı sonucuna varılmıştır. Çalışmada vimentin filamentlerinin, germ hücrelerinin seminifer epitele bağlanmasında Sertoli hücrelerinin bitişik spermatojenik hücre temaslarına bütünlüğünün korunmasında önemli bir role sahip olabileceğini de düşündürmüştür. Yine çalışmada vimentinin olası işlevlerinden biri olan hücreler arası boşluk kavşağı iletişimiyle birlikte spermatogenezin olgunlaşmasında önemli bir rol oynama rolü de gösterilmiştir. Bu çalışmadan elde edilen bulgularla, boğa ve koç üreme sisteminde vimentin antikorunun sergilediği benzer lokalizasyon modelinin her iki tür için ortak bir evrimsel köken ve muhtemelen de benzer üreme stratejileri önererek ilerde yapılacak olan çalışmalara ışık tutacağı kanaatindeyiz.

\section{KAYNAKLAR}

1. Lydka M, Kotula-Balak M, Kopera-Sobota I, Tischner M, Bilinska B. (2011). Vimentin Expression in Testes of Arabian Stallions. Equine Vet J. 43(2): 184-189.

2. Matthew DS, Matthew DA, Folmer JS, Zırkın BR. (2003). Reduced Intratesticular Testosterone Concentration Alters the Polymerization State of the Sertoli Cell Intermediate Filament Cytoskeleton by Degradation. Endocrinology. 144(12): 55305536.

3. Aslan Ş, Kocamış H, Nazlı M, Gülmez N. (2005). Immunohistochemical Distribution of Desmin and Vimentin in the Skin of Zavot Cattle. Turk J Vet Anim Sci. 29: 325-329.

4. Sasano H, Nakashima N, Matsuzaki O. et al. (1992). Testicular Sex Cord-Stromal Lesions: Immunohistochemical Analysis of Cytokeratin, Vimentin and Steroidogenic Enzymes. Virchows Archiv A Pathol Anat. 421: 163-169.

5. Aire TA, Ozegbe PC, Soley JT, Madekurozwa MC. (2008). Structural and Immunohistochemical Features of the Epididymal Duct Unit of the Ostrich (Struthio camelus). Anat Histol Embryol. 37: 296-302.

6. Dinges HP, Zatloukal K, Schmid C, Mair S, Wirnsberger G. (1991). Co-expression of Cytokeratin and Vimentin Filaments in Rete Testis and Epididymis. Virchows Archiv A Pathol Anat. 418:119-127.

7. Davidoff MS, Middendorff R, Pusch W. et al. (1999). Sertoli and Leydig Cells of the Human Testis Express Neurofilament Triplet Proteins. Histochem Cell Biol. 111:173-187.

8. Beyaz F, Küçük Bayram G, Alan E. 2009. Vimentin, Sitokeratin, $\alpha$-SMA ve Desmin'in Yeni Zellanda Tavşanı Testis ve Epididimisindeki Immunohistokimyasal Ekspresyonu. Erciyes Üniv Vet Fak Derg. 6(2) 111-119.

9. Devkota B, Sasaki M, Takahaski KI, et al. (2006). Postnatal Developmental Changes in Immunohistochemical Localization of $\alpha$-Smooth Muscle Actin (SMA) and Vimentin in Bovine Testis. J Reprod Dev. 52: 43-49.

10. Steger K, Schimmel M, Wrobel KH. (1994). Immunocytochemical Demonstration of Cytoskeletal Proteins in Seminiferous Tubules of Adult Rams and Bulls. Arch Histol Cytol. 57: 1.

11. Devkota B, Sasaki M, Matsui M, Montoya CA, Miyake YI. (2006). Alterations in the İmmunohistochemical Localization Patterns of $\alpha$-Smooth Muscle Actin (SMA) and Vimentin in the Postnatally Developing Bovine Cryptorchid Testis. J Reprod Dev. 52: 329-334.

12. Tung PS, Rosenior J, Fritz IB. (1987). Isolation and Culture of Ram Rete Testis Epithelial Cells: Structural and Biochemical Characteristics. Biol Reprod. 36: 1297-1312.

13. Komatsu T, Yamamoto Y, Atoji Y, Tsubota T, Suzuki Y. (1998). Immunohistochemical Demonstration of Cytoskeletal Proteins in the Testis of the Japanese Black Bear, Ursus thibetanus japonicus. Anat Histol Embryol. 27: 209-213.

14. Rodriguez A, Rojas MA, Obregon EB, Urquieta B. et al. (1999). Distribution of Keratins, Vimentin, and Actin in the Testis of Two South American Camelids: Vicuna (Vicugna vicugna) and Llama (Lama glama). An Immunohistochemical Study. Anat Rec. 254: 330-335.

15. Matthew DS, Matthew DA, Folmer JS, Zirkin BR. (2003). Reduced Intratesticular Testosterone Concentration Alters the Polymerization State of the Sertoli Cell Intermediate Filament Cytoskeleton by Degradation of Vimentin. Endocrinology. 144(12): 5530-5536. 
16. Richburg JH, Boekelheide K. (1996). Mono-(2-ethylhexyl) Phthalate Rapidly Alters both Sertoli Cell Vimentin Filaments and Germ Cell Apoptosis in Young Rat Testes. Toxicol Appl Pharmacol. 137: 42-50.

17. Zhang ZH, Hu ZY, Song XX. et al. (2004). Disrupted Expression of Intermediate Filaments in the Testisof Rhesus Monkey after Experimental Cryptorchidism. Int J Androl. 27: 234-239.

18. Aumfiller G, Schulze C, Viebahn C. (1992). Intermediate Filaments in Sertoli Cells. Microsc Res Tech. 20: 50-72.

19. Allard EK, Johnson KJ, Boekelheide K. (1993). Colchicine Disrupts the Cytoskeleton of Rat Testis Seminiferous Epithelium in a Stage Dependent Manner. Biol Reprod. 48: 143-153.

20. Steger K, Wrobel KH. (1994). Immunohistochemical Demonstration of Cytoskeletal Proteins in the Ovine Testis during Ppostnatal Development Anat Embryol. 189: 521-530.

21. Czernobilsky B, Moll R, Levy R, Franke WW. (1985). Co-expression of Cytokeratin and Vimentin Filaments in Mesothelial, Granulosa and Rete Ovarii Cells of the Human Ovary. Eur J Cell Biol. 37: $175-90$
22. Achtstatter T, Moll R, Moore B, Franke WW. (1985). Cytokeratin Polypeptide Patterns of Different Epithelia of the Human Male Urogenital Tract. J Histochem Cytochem. 33: 415-426.

23. Kasper M, Stosiek P. (1989). Immunohistochemical Investigation of Different Cytokeratins and Vimentin in the Human Epididymis from the Fetal Period up to Adulthood. Cell Tissue Res. 257: 661-664.

24. Wakui, S., M. Furusato, S. Ushigome, and Y. Kano. (1994). Coexpression of Different Cytokeratins, Vimentin and Desmin in the Rete Testis and Epididymis of the Dog. J Anat. 184: 147151.

\section{Sorumlu Yazar:}

Fatma ÇELENK

Diyarbakır Tarım ve Orman İ Müdürlüğü, Gıda ve Yem Şube Müdürlüğü, Diyarbakır, TÜRKIYE

E-posta: fatmakyn@gmail.com 